Araştırma Makalesi - Research Article

\title{
Düşme Tespit Sistemlerinde Aktivite Sınıfı Sayısının Etkisinin Araştırılması
}

\author{
Sitk1 Kocaoğlu ${ }^{*}$ \\ Geliş / Received: 03/04/2020 \\ Revize / Revised: 18/11/2020 \\ Kabul / Accepted: 25/11/2020 \\ ÖZ \\ $\mathrm{Bu}$ çalışmada, yaşlı bireyler için geliştirilen düşsme tespit sistemlerinde, makine öğrenmesi tabanlı \\ sınıflandırıcılarda sınıf sayısııın azaltılmasının doğruluk seviyesine katkısı araştırılmıştır. Çalışma kapsamında \\ internette açık erişime sunulmuş bir veriseti kullanılmış, aktivite ve postür belirlemede sıkça kullanılan öznitelikler \\ çıkarılmış ve MATLAB Machine Learning Framework'de bulunan sınıflandırıcıların tümü kullanılarak en başarılı \\ sınıflandırıcının tahlili makine öğrenmesi metriklerine göre yapılmıştır. Sınıf sayısı kademeli olarak azaltılıp \\ başarıya etkisi incelenmiştir. Başlangıç aşamasında sınıf sayısı azaltılmadan yapılan sınıflandırmada en başarılı \\ sınıflandırıcı olarak Kübik Destek Vektör Makinesi (Cubic SVM)algoritması belirlenmiştir. Bu algoritmayı \\ kullanarak gerçekleştirilen sınıflandırmada başarı \% 96,4 olmuştur. Problemin doğasına da uygun olarak \\ literatürdeki çalışmaların aksine sınıf sayısı 2'ye düşürüldüğünde $\mathrm{k}$ en yakın komşuluk (KNN) algoritması ile \\ düşmeler \%99,3 oranında doğru şekilde belirlenmiştir.
}

Anahtar Kelimeler- Düşme Tespit Sistemi, Makine Öğrenmesi, İvme Sensörü, Sınıf Sayısı

1*Sorumlu yazar iletişim: sitki.kocaoglu@klu.edu.tr (https://orcid.org/0000-0003-1048-9623)

Elektronik ve Otomasyon Bölümü, Kırklareli Üniversitesi, Teknik Bilimler Meslek Yüksekokulu, Kırklareli, Türkiye 


\title{
Investigating the Impact of Activity Class Number in Fall Detection Systems
}

\begin{abstract}
In this study, the contribution of reducing the number of classes in the machine learning based classifiers to the accuracy level of the fall detection systems developed for older individuals is investigated. Within the scope of the study, a public dataset is used and the appropriate data source is determined, the features frequently used in determining the activity and posture are extracted and the analysis of the most successful classifier is made according to the machine learning metrics using all the classifiers in the MATLAB Machine Learning Framework. The number of classes is gradually decreased and its effect on success is examined. The classification carried out with the Cubic Support Vector Machine (Cubic SVM) algorithm, which is determined as the most successful classifier in the classification without reducing the number of classes at the initial stage, is $96.4 \%$. In accordance with the nature of the problem, contrary to the studies in the literature, when the number of classes is reduced to two, the falls are correctly determined by $99.3 \%$ by using k nearest neighbor algorithm.
\end{abstract}

Keywords- Fall Detection System, Machine Learning, Accelerometer, Number of Classes 


\begin{tabular}{|c|c|c|}
\hline & $\begin{array}{l}\text { BŞEÜ Fen Bilimleri Dergisi } \\
7(2), 886-895,2020\end{array}$ & $\begin{array}{r}\text { BSEU Journal of Science } \\
\text { DOI: } 10.35193 / \text { bseufbd.714198 }\end{array}$ \\
\hline $\begin{array}{l}\text { BilLECIKSEYHEDEBALI } \\
\text { ONIVERSITESI }\end{array}$ & & 8-7575 (http://dergipark.gov.tr/bseufbd) \\
\hline
\end{tabular}

\section{INTRODUCTION}

According to the United Nations' World Population Expectations 2019 report, the world population, which was 7.7 billion in mid-2019, will increase to 9.7 billion by 2050, and individuals over 65, now constituting $9 \%$ of the population, while in 2050 this will increase to $17 \%$. The Potential Support Rate, that is, the ratio of the number of individuals at the age of working (25-64 years old) to the number of individuals over 65, is expected to fall below 2 by 2050 for the European continent [1]. In 2050, the ratio of elderly individuals to total population will reach at least twice by today. In the report, Turkey is also included in the category of countries with rapidly aging. While the number of individuals over 65 is 7.28 million in our country, it is predicted that it will be 19.5 million in 2050 [2,3] (Figure 1). In addition, due to the rapid participation of women in working life and the decrease in the number of individuals in the family, it is observed that the elderly individuals, whose numbers are increasing rapidly, often live at certain times of the day or completely alone. This situation indicates that additional preventions should be taken for health monitoring and care of the elderly in the coming years.
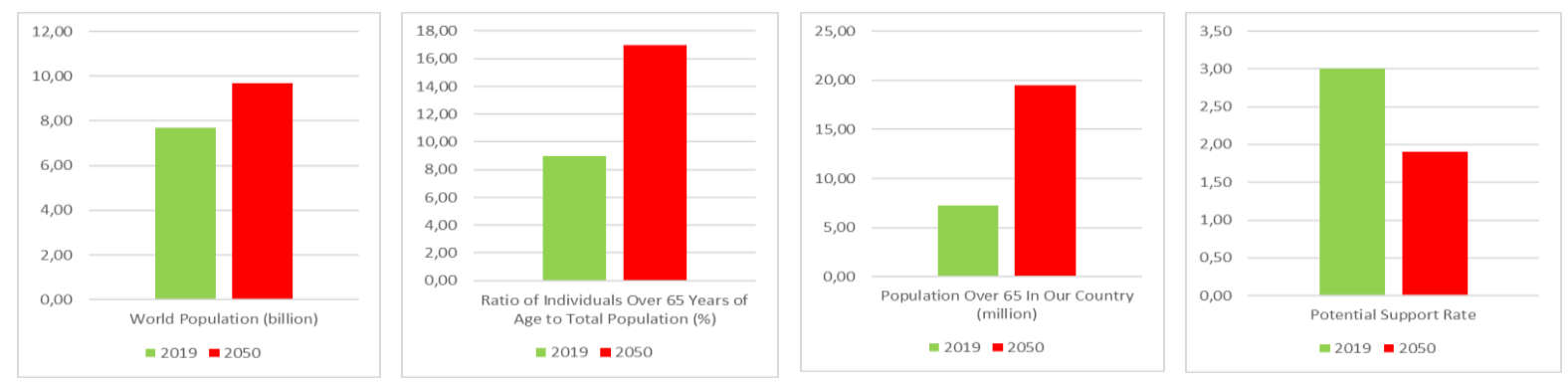

Figure1. Statistical data about aging

The number of falls increases with the biological change that occurs due to the increase in age. Falls are the second most common cause of death in accidental and unintentional injuries worldwide. Approximately 646 thousand people lose their lives in the world as a result of falling, and the most common age group is $65+$. As a result of nearly 37 million falls per year, people apply to clinics for medical assistance [4]. It is an important problem for older individuals to fall, especially when they are alone at home. While bone fractures occur in some of the fall cases in elderly individuals, no significant physiological damage occurs in $20 \%$ of the falls. However, as a result of the fact that the individual cannot get up of the ground without help, it is seen that his health condition deteriorates due to the long stay on the ground. Statistics show that about half of the elderly who have been lying on the ground for a long time died within 6 months [5]. Although a number of preventions can be taken to prevent elderly individuals from falling in the home, it does not seem possible to significantly reduce the number of falls [6]. For this reason, when elderly individuals fall, it is vital to detect quickly and to provide medical support. Thus, fall detection systems are important components of home care technologies.

Fall detection systems have been one of the subjects of great interest for researchers since 2010. These systems can be examined in 3 main groups as below;

\section{i. Wearable Sensor Based Fall Detection Systems \\ ii. Ambient Sensor and Image Processing Based Fall Detection Systems \\ iii. Multimodal Fall Detection Systems}

The first prototype of automatic fall detection systems was introduced in 1998 by Williams et al. It was created by using a piezoelectric sensor [7]. The first fall detection system based on image processing was developed by $\mathrm{Wu}$ in 2000 based on motion velocity measurement [8]. The first system developed using a wearable sensor is the work of Prado et al. In this study, high frequency accelerations were measured, falls were detected, and data were collected by wireless communication [9]. Also, in 2002, Noury created the first fall detection sensor 
by combining the accelerometer, tilt sensor, and vibration sensor, but with the rule-based approach developed, the fall detection success was very low [10]. Health monitoring system developed by Kang et al in 2006 also includes fall detection system. In their study, fall detection was performed using the accelerometer and posture sensor within the sensor structure worn on the wrist, and falls were detected $91.3 \%$ accurately [11]. In the study of Nyan et al. in 2006, a multimodal fall detection system was realized for the first time by using a combination of camera and gyroscope [12]. In this study, back and lateral falls were tried to be determined. In their study, as in previous studies, limit values were determined and activities were decided as whether fall or not. With the development of smart phones, it is seen that they are frequently used in fall detection systems. However, it is observed that the fall detection systems realized with the accelerometers found in the phones are able to perform fall detection with lower accuracy compared to other accelerometer-based systems [13]. After the Microsoft Company developed the sensor-camera system called Kinect, fall detection systems were developed by many researchers using it [14].

In the literature, the following components are found in wearable systems; accelerometers, gyroscopes, magnetometers, barometric pressure sensors, pulse measurement sensors, blood pressure measurement sensors, posture measurement combined sensors (AHRS), electromyograms (EMG), electroencephalographs (EEG), and altitude sensors. In the ambient sensor and image processing-based fall detection systems, one or more cameras or ambient sensors are placed in the room where the elderly person is living. Here, falling activity is detected by approaches, such as shape determination, immobility determination, shape change determination, posture determination, and head movement speed determination. As ambient sensors, there are studies using infrared sensors, microphones to detect the sound caused by falling, vibration sensors to detect ground vibration, bio-radar and infrared thermal sensors. In multimodal fall detection systems, the wearable sensor is connected to the body of the elderly and at the same time follow-up is maintained with camera and ambient sensors. The aim is to increase the classification accuracy.

Classification accuracy of fall detection systems is important, but a more important issue is the acceptance by elderly individuals. In particular, cameras in image processing systems are rejected by elderly individuals due to privacy concerns. In addition, one of the important limitations of image processing-based systems is their datasets, which either no furniture is available in the room or little furniture not moved at all. In addition, the ambient light level is kept constant during data collection experiments of image processing-based systems and it is not known to what extent the success of the system will be affected when different values are encountered. In practice, the camera installed in only one room of the house can only detect a fall in that room and in cases where there is more than one person in the room, the risk of falling into blackness increases. Likewise, wearable sensorbased systems should be designed in such a way that they do not discomfort the individual and do not need to be removed during activities of daily living (ADLs).

In the process of developing the fall detection system, a dataset that includes ADLs and fall movements is created. The fact that the dataset accurately reflects the ambient conditions and movement patterns of the elderly individuals is essential to the success of the system. However, since it is not possible to make the fall tests using elderly subjects, the fall tests in all data sets in the literature were carried out with individuals at a young age. This situation causes a significant decrease in the success rate of the system when it is put into practice. It is seen that most of the researchers share the datasets publicly on the internet in order to make them available to other researchers. In addition, many researchers who make image-based fall detection use open access images on the internet sites as datasets [15].In fall detection systems, activity classification is done based on threshold value, rule-based or machine learning. Threshold value-based systems are generally simple applications that can distinguish a single fall pattern and do not give accurate results when tested in datasets of various realistic falls. The most important problem of rule-based systems is feature constraints. Classification success remains low due to the linear evaluation of a few specific features. In most of the fall detection systems developed today are using deep learning and machine learning algorithms, such as Decision Tree (DT), k Nearest Neighbor (k-NN), Support Vector Machine (SVM) and Naif Bayes (NB). In these studies, it is seen that the falling pattern diversity and classification success are higher since more features can be used in parallel with each other compared to other methods.

In this study, SisFall dataset, which was made public in 2017, is used [16]. The data are classified with various machine learning algorithms and the contribution of reducing classification diversity to success is investigated.k-NN algorithm with $99.3 \%$ accuracy is determined as the most successful method. 


\begin{tabular}{|c|c|c|}
\hline & $\begin{array}{l}\text { BŞEÜ Fen Bilimleri Dergisi } \\
7(2), 886-895,2020\end{array}$ & $\begin{array}{l}\text { BSEU Journal of Science } \\
\text { DOI: } 10.35193 / \text { bseufbd. } 714198\end{array}$ \\
\hline & & 88-7575 (http://dergipark.gov.tr/bseufbd) \\
\hline
\end{tabular}

\section{MATERIALS AND METHODS}

\section{A. Dataset}

The dataset used in this study is created using 38 healthy subjects consisting of young and old individuals. Each subject repeated the movements listed in Table 1 five times. The dataset includes 15 different falling movements and 19 types of ADL. In this study, 8 types of falls and 8 types of daily activities are used to reduce the size of the data. The fall classes from F01 to F08 and the ADLs from D01 to D08 are used. During the experiments, a wearable sensor placed in belt of the subjects (Figure 2).This sensor structure contains data from two 3 -axis accelerometers and one 3 -axis gyroscope at $200 \mathrm{~Hz}$ frequency.

Table 1. Activities performed by subjects [16]

\begin{tabular}{|c|c|c|}
\hline Code & Activity & Duration (s) \\
\hline F01 & Fall forward while walking, caused by a slip & 15 \\
\hline F02 & Fall backward while walking, caused by a slip & 15 \\
\hline F03 & Lateral fall while walking, caused by a slip & 15 \\
\hline F04 & Fall forward while walking, caused by a trip & 15 \\
\hline F05 & Fall forward while jogging, caused by a trip & 15 \\
\hline F06 & Vertical fall while walking, caused by fainting & 15 \\
\hline F07 & Fall while walking with damping, caused by fainting & 15 \\
\hline F08 & Fall forward when trying to get up & 15 \\
\hline F09 & Lateral fall when trying to get up & 15 \\
\hline F10 & Fall forward when trying to sit down & 15 \\
\hline F11 & Fall backward when trying to sit down & 15 \\
\hline F12 & Lateral fall when trying to sit down & 15 \\
\hline F13 & Fall forward while sitting, caused by fainting & 15 \\
\hline F14 & Fall backward while sitting, caused by fainting & 15 \\
\hline F15 & Lateral fall while sitting, caused by fainting & 15 \\
\hline D01 & Walking slowly & 100 \\
\hline D02 & Walking quickly & 100 \\
\hline D03 & Jogging slowly & 100 \\
\hline D04 & Jogging quickly & 100 \\
\hline D05 & Walking upstairs and downstairs slowly & 25 \\
\hline D06 & Walking upstairs and downstairs quickly & 25 \\
\hline D07 & Slowly sit and get up in a half-height chair & 12 \\
\hline D08 & Quickly sit and get up in a half-height chair & 12 \\
\hline D09 & Slowly sit and get up in a low-height chair & 12 \\
\hline D10 & Quickly sit and get up in a low-height chair & 12 \\
\hline D11 & Sitting, trying to get up, and collapse into a chair & 12 \\
\hline D12 & Sitting, lying slowly, wait a moment, and sit again & 12 \\
\hline D13 & Sitting, lying quickly, wait a moment, and sit again & 12 \\
\hline D14 & Changing position while lying (back-lateral-back) & 12 \\
\hline D15 & Standing, slowly bending at knees, and getting up & 12 \\
\hline D16 & Standing, slowly bending w/o knees, and getting up & 12 \\
\hline D17 & Standing, get into and get out of a car & 25 \\
\hline D18 & Stumble while walking & 12 \\
\hline D19 & Gently jump without falling (to reach a high object) & 12 \\
\hline
\end{tabular}




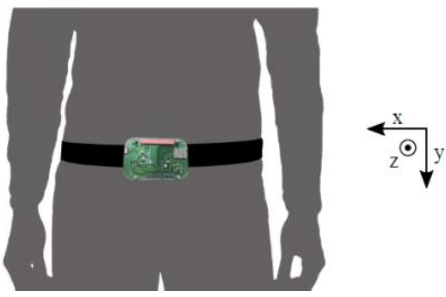

Figure 2. Sensor placement [16]

\section{B. Feature Extraction}

The features used frequently in the activity and posture determination studies in the literature are determined and calculated. The features used are shown in Table 2.

Table 2. Features

\begin{tabular}{|c|c|c|c|c|c|}
\hline $\begin{array}{c}\text { Feature } \\
\text { No }\end{array}$ & Feature & Equation / Definition & $\begin{array}{c}\text { Feature } \\
\text { No }\end{array}$ & Feature & Equation / Definition \\
\hline 1 & Mean & $\mu=\frac{1}{N} \sum_{i=1}^{N} x_{i}$ & 7 & Minimum & Min. term of data \\
\hline 2 & $\begin{array}{l}\text { Standard } \\
\text { deviation }\end{array}$ & $\sigma=\sqrt{\frac{1}{N}} \sum_{i=1}^{N}\left(x_{i}-\mu\right)^{2}$ & 8 & Kurtosis & $g_{2}=\frac{\frac{1}{N} \sum_{i=1}^{N}\left(x_{i}-\mu\right)^{4}}{\frac{1}{N} \sum_{i=1}^{N}\left(x_{i}-\mu\right)^{2}}$ \\
\hline 3 & Variance & $\sigma^{2}=\frac{1}{N} \sum_{i=1}^{N}\left(x_{i}-\mu\right)^{2}$ & 9 & Skewness & $g_{1}=\frac{\frac{1}{N} \sum_{i=1}^{N}\left(x_{i}-\mu\right)^{3}}{\frac{1}{N} \sum_{i=1}^{N}\left(x_{i}-\mu\right)^{2}}$ \\
\hline 4 & Sum & $s=\sum_{i=1}^{N} x_{i}$ & 10 & Band power & Average power of data \\
\hline 5 & Median & Midterm of data & 11 & $\begin{array}{l}\text { Root mean } \\
\text { square }\end{array}$ & $r m s=\sqrt{\frac{1}{N}} \sum_{i=1}^{N} x_{i}^{2}$ \\
\hline 6 & Maximum & Max. term of data & & & \\
\hline
\end{tabular}

\section{Classification}

Classification is made by using MATLAB Machine Learning Framework. The data is separated as $70 \%$ train, 30\% test, and 10-folds cross validation is selected. Classification experiments are carried out in 3 different ways. First of all, the movements in 16 different classes were tried to be determined. In the second approach, falls are grouped in a single class and ADLs are classified separately. Finally, only 2 classes are created and classified as falls and ADLs. When evaluating the performance of the system in terms of machine learning metrics, recall, precision, and F-score are calculated. Four important evaluation metrics are calculated as follows using number of true positives (TP), number of false positives (FP), number of false negatives (FN), and number of true negatives (TN). 


\begin{tabular}{|c|c|c|}
\hline & $\begin{array}{l}\text { BŞEÜ Fen Bilimleri Dergisi } \\
7(2), 886-895,2020\end{array}$ & $\begin{array}{l}\text { BSEU Journal of Science } \\
\text { DOI: } 10.35193 / \text { bseufbd. } 714198\end{array}$ \\
\hline ERSI & & 58-7575 (http://dergipark.gov.tr/bseufbd) \\
\hline
\end{tabular}

$$
\begin{aligned}
& \text { Recall }=\frac{T P}{T P+F N} \\
& \text { Precision }=\frac{T P}{T P+F P} \\
& F-\text { score }=2 x \frac{\text { Recall } x \text { Precision }}{\text { Recall }+ \text { Precision }}
\end{aligned}
$$

\section{RESULTS}

\section{A. 16 Class Approach}

The aim in this approach is to determine all the falling movements with their directions and all ADLs with their varieties during daily life. Classification accuracy is $96.4 \%$ due to the high number of classes here. The most successful algorithm in this approach is cubic SVM (Figure 3). Performance parameters are presented in Table 3.
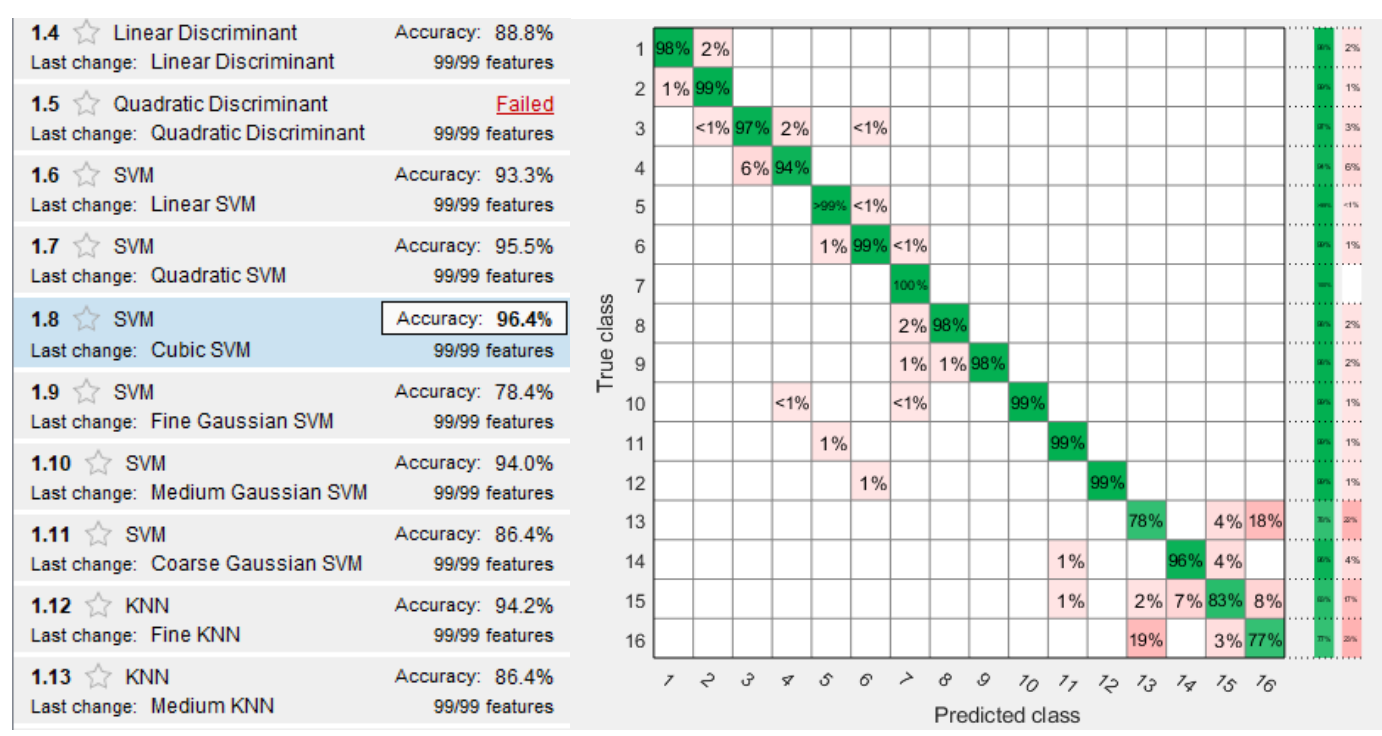

Figure 3. 11 class approach results

Table 3. Performance metrics of 11 class approach

\begin{tabular}{lcccccccccccccccccc}
\hline & $\mathbf{1}$ & $\mathbf{2}$ & $\mathbf{3}$ & $\mathbf{4}$ & $\mathbf{5}$ & $\mathbf{6}$ & $\mathbf{7}$ & $\mathbf{8}$ & $\begin{array}{c}\text { All } \\
\text { Falls }\end{array}$ & $\mathbf{9}$ & $\mathbf{1 0}$ & $\mathbf{1 1}$ & $\mathbf{1 2}$ & $\mathbf{1 3}$ & $\mathbf{1 4}$ & $\mathbf{1 5}$ & $\begin{array}{c}\mathbf{1 6} \\
\text { All } \\
\text { ADL } \\
\text { 's }\end{array}$ \\
\hline Recall & 0,99 & 0,99 & 0,95 & 0,98 & 0,99 & 0,99 & 0,96 & 0,99 & 0,99 & 1 & 1 & 0,99 & 1,00 & 0,79 & 0,93 & 0,89 & 0,69 & 1 \\
Precision & 0,98 & 0,99 & 0,97 & 0,94 & 0,99 & 0,99 & 1 & 0,99 & 1 & 0,99 & 0,99 & 0,99 & 0,99 & 0,78 & 0,96 & 0,83 & 0,77 & 0,99 \\
F-score & 0,98 & 0,99 & 0,96 & 0,96 & 0,99 & 0,99 & 0,98 & 0,99 & 0,99 & 0,99 & 0,99 & 0,99 & 0,99 & 0,78 & 0,94 & 0,86 & 0,73 & 0,99 \\
\hline
\end{tabular}

By the detailed examination of this approach in Table 3, the system is successful in classification according to the types of falls. However, when Figure 3 is examined, it can be seen that generally the misclassified falls are incorrectly recorded as another type of fall. Thus, examining all of the falls as a single group will increase the classification success. The falling direction during the use of the system in daily life is not important anyway. When the "All Falls" column is examined in Table 3, the 99\% F-score value indicates that the falls are actually accurately distinguished. In fact, the samples that are dropped and recorded as ADL are only in the "walking" classes 9 and 10 and "jogging" classes 11 and 12 . 


\begin{tabular}{|c|c|c|}
\hline & $\begin{array}{l}\text { BŞEÜ Fen Bilimleri Dergisi } \\
7(2), 886-895,2020\end{array}$ & $\begin{array}{r}\text { BSEU Journal of Science } \\
\text { DOI: } 10.35193 / \text { bseufbd. } 714198\end{array}$ \\
\hline & & 88-7575 (http://dergipark.gov.tr/bseufbd) \\
\hline
\end{tabular}

Similarly, when ADLs are examined, the fact that the F-score value in the "All ADLs" column is 99\% shows that ADLs can be easily separated from the falls. There is not any observation with true class ADL and misclassified as fall.

\section{B. 9 Class Approach}

Due to the complexity of distinguishing the falls from each other, all falls have been brought into a single class. In this way, it is seen in Figure 4 that the overall classification success increased from $96.4 \%$ to $96.9 \%$. The cubic SVM which is the most successful model in the previous approach is the most successful classifier in this approach too.

\begin{tabular}{|c|c|}
\hline $\begin{array}{l}1.6 \text { SVM } \\
\text { Last change: Linear SVM }\end{array}$ & $\begin{array}{l}\text { Accuracy: } 95.6 \% \\
\text { 99/99 features }\end{array}$ \\
\hline $\begin{array}{l}1.7 \text { SVM } \\
\text { Last change: Quadratic SVM }\end{array}$ & $\begin{array}{l}\text { Accuracy: } 96.3 \% \\
\text { 99/99 features }\end{array}$ \\
\hline $\begin{array}{l}1.8 \text { SVM } \\
\text { Last change: Cubic SVM }\end{array}$ & $\begin{array}{r}\text { Accuracy: } 96.9 \% \\
99 / 99 \text { features }\end{array}$ \\
\hline $\begin{array}{l}1.9 \approx \text { SVM } \\
\text { Last change: Fine Gaussian SVM }\end{array}$ & $\begin{array}{l}\text { Accuracy: } 70.6 \% \\
99 / 99 \text { features }\end{array}$ \\
\hline $\begin{array}{l}1.10 \approx \text { SVM } \\
\text { Last change: Medium Gaussian SVM }\end{array}$ & $\begin{array}{l}\text { Accuracy: } 95.6 \% \\
99 / 99 \text { features }\end{array}$ \\
\hline $\begin{array}{l}1.11 \text { SVM } \\
\text { Last change: Coarse Gaussian SVM }\end{array}$ & $\begin{array}{l}\text { Accuracy: } 89.0 \% \\
\text { 99/99 features }\end{array}$ \\
\hline $\begin{array}{l}1.12 \lesssim \mathrm{KNN} \\
\text { Last change: Fine KNN }\end{array}$ & $\begin{array}{l}\text { Accuracy: } 96.2 \% \\
99 / 99 \text { features }\end{array}$ \\
\hline $\begin{array}{l}1.13 \approx \mathrm{KNN} \\
\text { Last change: Medium KNN }\end{array}$ & $\begin{array}{l}\text { Accuracy: } 93.3 \% \\
\text { 99/99 features }\end{array}$ \\
\hline $\begin{array}{l}1.14 \Rightarrow \mathrm{KNN} \\
\text { Last change: Coarse KNN }\end{array}$ & $\begin{array}{l}\text { Accuracy: } 86.6 \% \\
99 / 99 \text { features }\end{array}$ \\
\hline $\begin{array}{l}1.15 \approx \mathrm{KNN} \\
\text { Last change: Cosine KNN }\end{array}$ & $\begin{array}{l}\text { Accuracy: } 93.5 \% \\
\text { 99/99 features }\end{array}$ \\
\hline KNN & Accuracy: $92.3 \%$ \\
\hline
\end{tabular}

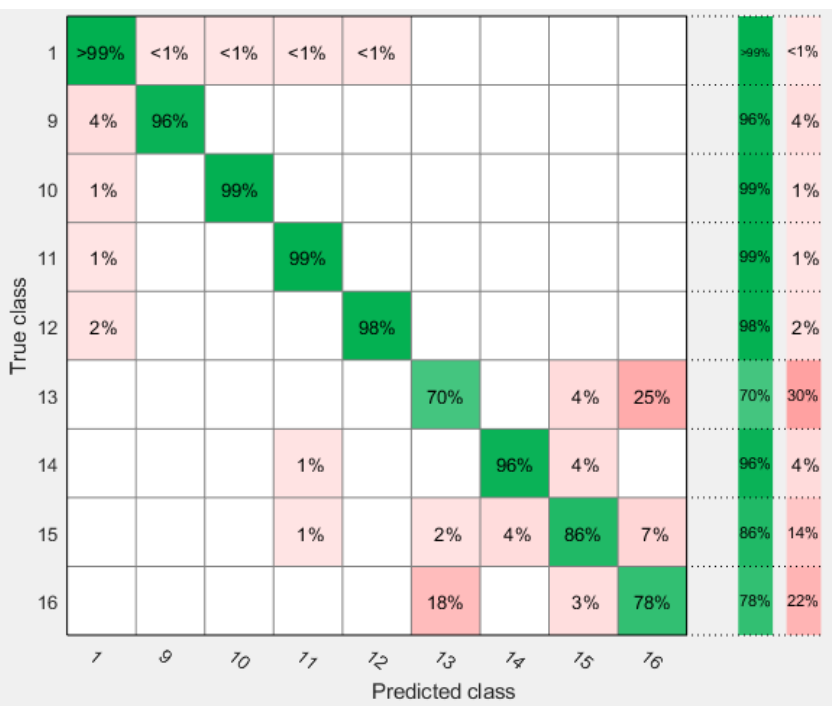

Figure4. 6 class approach results

Table 4. Performance metrics of 6 class approach

\begin{tabular}{lcccccccccc}
\hline & Falls & $\mathbf{9}$ & $\mathbf{1 0}$ & $\mathbf{1 1}$ & $\mathbf{1 2}$ & $\mathbf{1 3}$ & $\mathbf{1 4}$ & $\mathbf{1 5}$ & $\mathbf{1 6}$ & $\begin{array}{c}\text { All } \\
\text { ADL's }\end{array}$ \\
\hline Recall & 1 & 0,99 & 1 & 0,99 & 1 & 0,78 & 0,96 & 0,88 & 0,71 & 0,99 \\
Precision & 1 & 0,96 & 0,99 & 0,99 & 0,99 & 0,70 & 0,96 & 0,86 & 0,78 & 0,99 \\
F-score & 1 & 0,97 & 0,99 & 0,99 & 0,99 & 0,74 & 0,96 & 0,87 & 0,74 & 0,99 \\
\hline
\end{tabular}

When the complexity matrix given in Figure 4 is examined, it can be seen that nearly $100 \%$ of the falls can be classified correctly and recorded as falls. But ADL classification success is not very good. The rates of ADLs registered in the fall class are not high. Even the class 13 "Walking upstairs and downstairs slowly" and class 16 "Quickly sit and get up in a half-height chair" are the most problematic classes and these are reducing overall accuracy.

\section{2 Class Approach}

In this section, movements are divided into 2 classes as 1: Falls and 2: ADLs. Thus, the main goal is to determine the fall movements as accurately as possible. When Figure 5 is examined, it is seen that the theory has found a response. The success rate increased to $99.3 \%$. The most successful classifier is fine k-NN. 


\begin{tabular}{|c|c|c|}
\hline & $\begin{array}{l}\text { BŞEÜ Fen Bilimleri Dergisi } \\
7(2), 886-895,2020\end{array}$ & $\begin{array}{l}\text { BSEU Journal of Science } \\
\text { DOI: } 10.35193 / \text { bseufbd. } 714198\end{array}$ \\
\hline & & 88-7575 (http://dergipark.gov.tr/bseufbd) \\
\hline
\end{tabular}

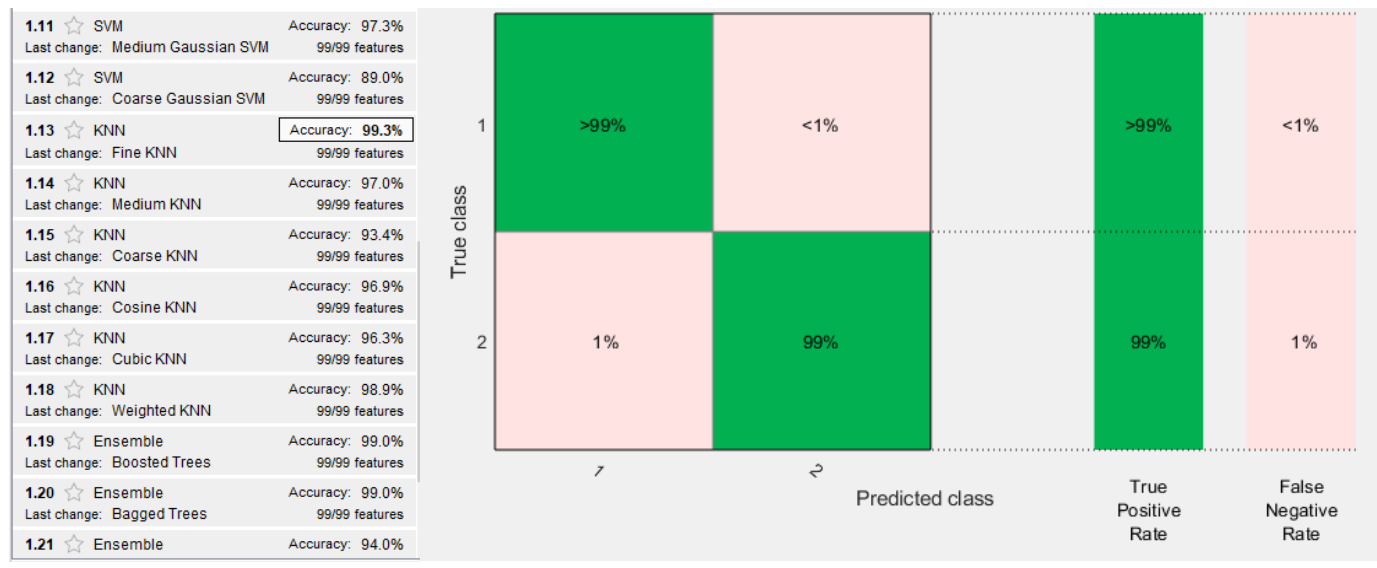

Figure 5. 2 class approach results

Table 5. Performance metrics of 2 class approach

\begin{tabular}{lc}
\hline & General \\
\hline Recall & 0,994 \\
Precision & 0,996 \\
F-score & 0,995 \\
\hline
\end{tabular}

The developed model is exported as a compact model and tested with test data that is separated in the beginning and the system had not met before. The classification accuracy that arises here is to confirm the study, only $0.6 \%$ of the data is classified incorrectly.

\section{CONCLUSION}

Within the scope of the study, it is aimed to develop a suitable machine learning model to be used in fall detection for elderly individuals. The aim is to propose a system that is suitable for use both in the home and outside. A system design is aimed with high accuracy and low cost, which elderly individuals will not refuse to use in daily life. Within the scope of the study, a very high classification success could be created by reducing the number of activity classes. The falls in daily life are very diverse. Falls occur as a result of complex interactions of risk factors. It is known that biological, behavioral, environmental and socio-economic factors have effects on the fall. Even when it is analyzed only by the age and gender of the individuals, it is seen that the fall types are different. For this reason, the systems that can detect all falls regardless of their direction and shape, rather than the systems that distinguish between falls in a certain way and direction, overlap with real life.

\section{LIMITS AND FUTURE WORK}

Falls are very rare movements compared to ADLs due to their nature. For this reason, it is nearly impossible to record by a sensor is placed on a subject and it falls naturally. The falls in the dataset used in this study are also artificial falls. Therefore, it may not be able to imitate natural falls very well. In addition, while creating dataset, falling measurements were taken only from young individuals and it is known that the activity dynamics of older individuals and young individuals are very different. However, due to ethical standards, it is not possible to do falling tests with elderly people.

In addition, while selecting the features, only the frequently used features in the literature are taken. The effect of the features on the classification success has not been investigated. The main purpose here is to observe the effect of the number of classes on success without any other factors. It is clear, however, that the success achieved shows that such improvements are not required. 


\section{REFERENCES}

[1] United Nations. (2019). World Population Prospects 2019. https://population.un.org/wpp/

[2] Turkish Republic Ministry of Family and Social Policies. (2013). Dormitory and elderly aging national action plan implementation program in Turkey.

https://www.tatd.org.tr/uploads/tbl_calisma_grubu_belgeleri/5bdc0c422b9e3_tbl_calisma_grubu_belgeleri 2018113514.pdf

[3] United Nations. (2019). World Population Ageing 2019.

ttps://www.un.org/en/development/desa/population/publications/pdf/ageing/WorldPopulationAgeing2019Report.pdf

[4] World Health Organization. (2018). Falls. https://www.who.int/news-room/fact-sheets/detail/falls

[5] Wild, D., Nayak, U.S.L., Isaacs B. (1981). How dangerous are falls in old people at home?. British Medical Journal (Clinical Research Edition), 282, 266-268.

[6] World Health Organization. (2007). Global report on falls Prevention in older Age. https://www.who.int/ageing/publications/Falls_prevention7March.pdf

[7] Williams, G., Doughty, K., Cameron, K., Bradley, D.A. (1998). A Smart Fall \& Activity Monitor for Telecare Applications. Proceedings of the 20th Annual International Conference of the IEEE 3, 1151-1154.

[8] Wu, G. (2000). Distinguishing fall activities from normal activities by velocity characteristics. Journal of Biomechanics. 33:1497-1500.

[9] Prado, M., Reina-Tosina, J., Roa, L. (2002). Distributed intelligent architecture for falling detection and physical activity analysis in the elderly. Proceedings of 18th Annual International Conference of the IEEE Engineering in Medicine and Biology Society; 3, 1910-1911.

[10] Noury, N. (2002). A smart sensor for the remote follow up of activity and fall detection of the elderly. Proceedings of 2nd Annual International IEEE-EMBS Special Topic Conference on Microtechnologies in Medicine and Biology.314-317.

[11] Kang, J.M., Yoo, T., Kim, H. C. (2006). A wrist-worn integrated health monitoring instrument with a telereporting device for telemedicine and telecare. IEEE Transactions on Instrumentation and Measurement. 55:1655-1661.

[12] Nyan, M. N., Tay, F. E. H., Tan, A.W.Y., Seah K. H. W. Distinguishing fall activities from normal activities by angular rate characteristics and high-speed camera characterization. Medical Engineering and Physics. $28,842-849$.

[13] Lee, R. Y. W., Carlisle A. J. (2011). Detection of falls using accelerometers and mobile phone technology. Age Ageing. 40, 690-696.

[14] Han, J., Shao, L., Xu, D., Shotton, J. (2013). Enhanced computer vision with Microsoft Kinect sensor: A review. IEEE Transactions on Cybernetics. 43, 1318-1334.

[15] Kyriakopoulos, G., Ntanos, S., Anagnostopoulos, T., Tsotsolas, N., Salmon, I., Ntalianis, K. Internet of Things ( IoT ) -Enabled Elderly Fall Verification, Exploiting Temporal Inference Models in. Smart Homes. International Journal of Environmental Research and Public Health. 17, 1-14.

[16] Sucerquia, A., López, J. D., Vargas-Bonilla, J. F. (2017). SisFall: A fall and movement dataset. Sensors (Switzerland).17, 1-14. 